\title{
Lecturer Support and Their Performance at Universities: Mediating Role of Commitment
}

\author{
Sarkhel Shawkat Mohammed ${ }^{1}$ \\ ${ }^{1}$ College of Public Administration and Natural Resources Management, Charmo University, \\ Suleymaniyah, Iraq \\ ${ }^{1}$ Business and Management Department, Tishk International University, Suleymaniyah, Iraq \\ Correspondence: Sarkhel Shawkat Mohammed, Charmo University, Suleymaniyah, Iraq. \\ Email: sarkhel.mohammed@ charmouniversity.org
}

Doi: 10.23918/ijsses.v8i2p53

\begin{abstract}
Perceived support and commitment feelings are vital factors for improved performance. In this respect, the current study aims to investigate the key role of perceived co-worker support (PCS), perceived supervisor support (PSS), and perceived organizational support (POS) on lecturer's affective commitment (AC) and continuous commitment (CC), and in turn on their academic performance. To do this, a survey questionnaire was developed and distributed amongst various university faculties in the Kurdistan Region of Iraq. In total, 204 data points were collected. Based on the results, it has been observed that perceived coworker support and perceived organizational support have significant impact on continuous commitment. Additionally, perceived co-worker support and perceived supervisor support were shown to have significant positive impact on university faculties' performance.
\end{abstract}

Keywords: Perceived Co-Worker Support, Perceived Supervisor Support, Perceived Organizational Support, Affective Commitment, Continues Commitment, Academic Performance

\section{Introduction}

Due to the vital role they play in teaching, training, research, and technology, universities can be considered the backbone of the modern society. In teaching and training for example, universities not only offer students the necessary knowledge, skills and abilities for personality development and role fulfillment, but also, they provide the students proper vocational training for top tier jobs. Additionally, universities are at the forefront of research and technology. When disaster strikes, for instance, the world looks to the universities and the academic community for answers and solutions. Currently, universities and academicians around the world are trying hard to find a cure for the recent COVID-19 pandemic (Demir et al., 2020; Rashid et al., 2020; Sulich, 2019). Though, according to Sharma (2015) the most important thing that universities are doing is the offering of highly skilled alumni to the society. Through

Received: March 19, 2021

Accepted: June 2, 2021

Mohammed, S.S. (2021). Lecturer Support and Their Performance at Universities: Mediating Role of Commitment. International Social Sciences \& Educational Studies, 8(2), 53-75. 
this, universities can advance societies and alter social values or develop new ones. After all, it is university graduates who become future doctors, engineers, lawyers, entrepreneurs, managers, .... and leaders who run the country and decide on its future.

Given the importance of universities, we deemed it appropriate to conduct our study in the academic sector. Thus, the aim of this paper is to examine the mediating role of affective commitment (AC) between the effects of perceived co-worker support (PCS), perceived supervisor support (POS), and perceived organizational support (POS) on university staff's performance. The importance of this paper lies in it being one of the very few studies that examine these constructs in an academic context. To our knowledge, Saleem and Amin's paper is the only one that has attempted to do this (2013). Though, the authors have only examined the impact of organizational and supervisor support on career development and employee performance respectively. Our study adds to the literature by adding co-worker support and commitment elements as well.

The concept of support has been given considerable attention in the organizational theory literature (Byrne \& Hochwarter, 2008; Demir, 2020; DeConinck, 2010; Kalidass \& Bahron, 2015; Newman, Thanacoody $\&$ Hui, 2012). According to literature, employees can look to three areas as sources for support. First, they can receive the needed support from their fellow workers, which is called co-worker support. Co-worker support is defined as devoting desirable resources to a fellow employee (Caplan, Cobb, French, Harrison \& Pinneau, 1975). Co-worker support has been shown to contribute to both employees' affective commitment (Chiaburu \& Harrison, 2008; Rayton, 2006), and performance (Budur et al., 2020; Limpanitgul, Robson, Gould-Williams, \& Lertthaitrakul, 2013). Second, employees can also be supported by their immediate superiors, which is referred to as supervisor support. Saleem and Amin (2013) defined supervisor support as the extent to which supervisors' value their subordinates' contributions to the organization and care for their well-being. Supervisor support has been proven to cause organizational support (Budur, 2018; DeConinck, 2010; Campbell \& Allen, 2007; Maertz Jr, Griffeth,), and enhance employees' affective commitment (Casper, Harris, Taylor-Bianco, \& Wayne, 2011) and performance (Shanock \& Eisenberger, 2006; Budur \& Demir, 2019; Zema \& Sulich, 2015). Finally, employees can be supported by their organizations, which is termed organizational support. Rhoades and Eisenberger defined organizational support as the extent to which an organization values its employees' contributions and cares for their well-being (2002). Organizational support has been reported to correlate positively to both employees' affective commitment (Kalidass \& Bahron, 2015; Mohammed \& Shahin, 2020; Panaccio \& Vandenberghe, 2009) and performance (Byrne \& Hochwarter, 2008; Demir and Budur, 2019; Loi, Hang-Yue, \& Foley, 2006). It is worth mentioning that compared to supervisor support and organizational support, co-worker support has received significantly less attention, which adds to the importance of our paper. Because we study the impact of co-worker support on employees' affective commitment and performance.

Commitment is another organizational element that is widely studied (Aube, Rousseau, \& Morin, 2007; Ito \& Brotheridge, 2005; Mercurio, 2015; Panaccio \& Vandenberghe, 2009; Mart, 2013a; Mart, 2013b). The most comprehensive paper on organizational commitment was published by Meyer and Allen (1991), in which the authors have identified three types of organizational commitment, specifically, affective commitment (AC), normative commitment (NC), and continuance commitment (CC). Simply put, 
affective commitment is when an employee is emotionally invested in the organization. Normative commitment is when the sole reason for an employee's association with the organization is his/her feeling of obligation. Continuance commitment is when an employee is forced to stay in an organization because of the acute costs associated with leaving (ibid). Affective commitment is considered by Mercurio (2015) the essence of organizational commitment. Perhaps due to the fact that employees who are affectively committed seem to continue with their organizations because they want to, as opposed to normatively committed employees who stay because they think it is their moral duty, and continuance committed employees who remain because they have no other option or they have costlier options (Rashid, Sambasivan, \& Johari, 2003; Meyer, Allen, \& Smith, 1993). Also, affective commitment has been shown to improve employees' performance (Ferres, Connell, \& Travaglione, 2004; Chen \& Francesco, 2003).

\section{Literature Review}

\subsection{Perceived Co-Worker Support (PCS)}

Gone are the days where jobs were designed in a way that they could be performed by individual employees in a routine and steady fashion. Now, jobs are becoming more and more complex, which in most cases require the employees to cooperate with one another. This has encouraged many organizations to have their employees work in teams. In a paper published by Bishop, Scott, and Burroughs, it is reported that $78 \%$ of American organizations are using work teams in their businesses (2000). Having employees work together leads to increased interaction amongst them, which can alter the outcome of the organization. According to Bishop et al. (2000) having employees work in teams is a viable and easy strategy for improving productivity.

Regardless of whether organizations arrange their employees into groups or not, it has been observed that employees who struggle to express their true feelings tend to form communities with their co-workers within which they can freely express their feelings. This helps them deal with stressful working environments (Hochschild, 2012; Korczynski, 2003). This is testament to the role of co-workers in shaping the social environment within organizations (Schneider, 1987), and their influence in the workplace (Chiaburu \& Harrison, 2008). Depending on the nature of this influence (i.e., negative or positive), coworkers can make or break the working and social environment in any organization (Limpanitgul et al., 2013; Kavlu, 2020). In line with the importance of co-worker's support, Thoits (1983) stated that employees tend to value support received from their co-workers higher than support received from their superiors.

We have found a couple of definitions for co-worker support, and they both revolve around the idea of providing positive assistance to fellow employees. For example, Ladd and Henry define co-worker support as "employees' global beliefs concerning their co-workers' attitudes toward them" (2000), while Caplan et al. (1975) defined co-worker support as devoting desirable resources to a fellow employee. Here, "attitude" and "desirable resources" are the same thing, and they can be instrumental and/or emotional. Whereas, instrumental support, is helping an employee to perform a task, emotional support, is when an employee is provided with emotional support (e.g., asking how the employee is doing or listening to their problems) (Beehr, Jex, Stacy, \& Murray, 2000). 
Co-worker's impact on one another can be profound. According to Chiaburu \& Harrison (2008), coworkers can impact their fellow employees in both negative and positive ways. They call positive impact support, while negative impact is referred to as antagonism (ibid). Nonetheless, co-worker support or antagonism can influence employees' individual effectiveness, role perceptions, and work attitudes. When in doubt, co-workers can be a useful source of information and support. They can also improve employees' performance by giving crucial information about how to perform certain tasks (Limpanitgul et al., 2013; Zaim et al., 2020). Additionally, co-workers' support can improve the employees' job satisfaction and deepen their commitment to the organization (Limpanitgul et al., 2013; Chiaburu \& Harrison, 2008; Rayton, 2006). These results seem to hold true regardless of sector or type of organization. Since there is no reason that compels us to believe that higher education is any different and that co-worker support will yield different results, we hypothesize the following:

H1a: PCS improves the university lecturers' continuous commitment.

H1b: PCS improves the university lecturers' affective commitment.

H1c: PCS improves the university lecturers' work effort.

\subsection{Perceived Supervisor Support (PSS)}

A supervisor is someone who oversees the work of others and makes sure an activity, or a task is carried out the way his/her organization has intended. Although the lowest in the chain of command, supervisors are crucial for the success of any organization. Because they have the critical role of making sure their subordinates have the necessary knowledge, skills and abilities to perform their duties. Another important task of supervisors is providing positive and constructive feedback to their employees, which is what supervisor support is all about. Perceived supervisor support (PSS) is defined as the extent to which a supervisor values his/her subordinates' contributions to the organization and cares for their well-being (DeConinck, 2010; Eisenberger et al., 2002; Kottke \& Sharafinski, 1988; Saleem \& Amin, 2013).

The importance of supervisors lies in their ability to help the organization achieve its operational and administrative goals, and one way they can do this is by providing adequate support to their employees (Poturak et al., 2020). Because when employees feel supported, they tend to reciprocate this feeling of support by improving their performance and helping their superiors and organizations achieve their goals (Eisenberger et al., 2002; Saleem \& Amin, 2013; Shanock \& Eisenberger, 2006; Stinglhamber \& Vandenberghe, 2003). Additionally, according to Ito and Brotheridge (2005), a supervisor's proper support to his/her subordinates can help them become better members of their organizations by continuously improving themselves. Moreover, by being supportive, supervisors help not only the organization and its employees, but themselves also (Torlak, Demir, \& Budur, 2021). Since by supporting their subordinates, supervisors can outshine the organization itself as a source for support (Maertz Jr et al., 2007), which can help them win the trust, respect, job satisfaction, and commitment of their employees (Torlak et al., 2021; Maertz Jr et al., 2007; Dirks \& Ferrin, 2002). Though, in order for supervisors to be supportive, they need to be supported, because when a supervisor feels supported, this feeling of support radiates to their subordinates. In other words, if an organization supports its supervisors, it is as if it has supported its employees (Shanock, \& Eisenberger, 2006). 
Adding to the importance of supervisor support, Kottke \& Sharafinski (1988) stated that employees care about their supervisors' view of them in exactly the same way they care about their organization's view of them. In fact, according to DeConinck \& Johnson, (2009) and Makanjee, Hartzer, \& Uys, (2006) employee's assessment of the organization can be affected and shaped by their assessment of their supervisors, because employees tend to see their immediate superiors as extensions of the organization itself (Makanjee et al., 2006; Rhoades \& Eisenberger, 2002; Eisenberger et al., 2002; Eisenberger, Huntington, Hutchison, \& Sowa, 1986; Levinson, 1965). Therefore, it is very important for supervisors to support their subordinates.

Extensive research has gone into studying the effects of perceived supervisor support on various organizational aspects such as, employee turnover, affective commitment, perceived organizational support (POS), and employee performance. Though compared to the other organizational aspects, employee turnover has been paid significantly more attention (Newman et al., 2012; Tuzun \& Kalemci, 2011; DeConinck \& Johnson, 2009; Maertz Jr. et al., 2007; Gentry, Kuhnert, Mondore, \& Page, 2006; Payne \& Huffman, 2005; Eisenberger et al., 2002).

The effect of perceived supervisor support on affective commitment (AC) has been well documented. While studying the relationship of perceived supervisor support and perceived organizational support to the work-family conflict amongst Brazilian professionals, Casper and colleagues (2011) have noted that perceived supervisor support affects Brazilian professionals' affective commitment. Similarly, DeConinck \& Johnson have reported the effect of perceived supervisor support on sales employees' affective commitment (2009). Likewise, Maertz Jr et al. (2007), reported that perceived supervisor support affects social service providers' affective commitment. Also, in their study of a variety of organization, Rhoades, Eisenberger \& Armeli (2001) concluded that perceived supervisor support improves employees' affective commitment through perceived organizational support. Lastly, Kottke \& Sharafinski (1988) have reported the same thing.

Interestingly, research suggests that perceived supervisor support causes perceived organizational support (POS). For instance, DeConinck (2010) conducted a study in which he randomly selected 1000 advertising managers and concluded that perceived supervisor support led to their perceived organizational support. Likewise, Maertz Jr et al. (20070) have concluded that perceived supervisor support leads to perceived organizational support amongst social service providers. Also, Makanjee and colleagues (2006) concluded that perceived supervisor support leads to stronger perceived organizational support amongst radiographs. Their reasoning for this is the fact that the radiographs have come to the realization that their supervisors' evaluation of them is being conveyed to the top management, which has led them to believe that supervisor support is associated with organizational support (ibid). Further, perceived supervisor support has been found to cause perceived organizational support among retail employees (Shanock, \& Eisenberger, 2006). Also, in their study of public health organization employees, Ferres et al. (2004), noted that perceived supervisor support has generated perceived organizational support. Moreover, in their review of the literature, Rhoades and Eisenberger (2002) concluded that perceived supervisor support is a precursor for perceived organizational support, because employees see their supervisors as agents of the organization itself. 
Finally, on the effects of perceived supervisor support on employee performance, Saleem and Amin (2013) stated that academic staff who reported higher perceived supervisor support performed better than those who reported lower perceived supervisor support. Also, Shanock and Eisenberger (2006), reported that high perceived supervisor support leads to better performance among retail employees. Therefore, we propose the following:

H2a: PSS leads to stronger continuous commitment amongst the university staff.

H2b: PSS leads to stronger affective commitment amongst the university staff.

H2c: PSS leads to stronger work effort by the university staff.

\subsection{Perceived Organizational Support (POS)}

Perceived organizational support (POS) has stemmed from Gouldner's reciprocity concept (1960), and Blau's social exchange theory (1964). As per the concept of reciprocity and the theory of social exchange, high levels of perceived organizational support create a sense of obligation in the employees to repay their organization's support with sincere dedication and concern for its success in the future (Saleem \& Amin, 2013; Loi et al., 2006; Makanjee et al., 2006; Lynch, Eisenberger, \& Armeli, 1999; Shore \& Wayne, 1993; Eisenberger et al., 1986). One might think that reciprocation and social exchange can happen between human beings only, but it can happen between employees and their organizations also. Employees tend to think of their organizations as living beings by giving them humanlike attributes (Eisenberger et al., 1986). According to research, this personification of organizations by their employees is one of the enablers of perceived organizational support (Makanjee et al., 2006). Eisenberger and colleagues (1986) defined perceived organizational support as "the extent to which employees perceive that their contributions are valued by their organization and that the firm cares about their well-being" (p. 501). More recently, Rhoades \& Eisenberger (2002) defined perceived organizational support as the extent to which an organization values its employees' contributions and cares for their well-being.

If organizations want to thrive in today's competitive market, they need to have committed employees. For employees to be committed, they need to be supported by their organizations. Because employees will interpret their organization's support as its commitment to them, in return they will do their best to reciprocate their organization's support through improved commitment and care for its success in the future (DeConinck \& Johnson, 2009; Rhoades \& Eisenberger 2002; Shore \& Shore 1995). Research stresses the importance of maintaining balance between employees' contributions and the rewards they receive from their organizations. According to Aube et al. (2007), organizations can achieve this balance by adequately supporting their employees. Because perceived organizational support is considered by many a valued resource that when given to employees will indicate to them that the organization cares for their well-being and is willing to provide them with all the support and resources needed to perform their duties in the best possible way (Panaccio, \& Vandenberghe, 2009; Hutchison, 1997; Eisenberger et al., 1986).

Literature emphasizes the importance of perceived organizational support even before the employees have joined the organization. Because employees may use perceived organizational support as a way to measure the possible gain and symbolic and material benefits, they might receive from the organization 
(Eisenberger, Fasolo, \& Davis-LaMastro, 1990). After joining the organization, perceived organizational support may also be used to decide whether to stay or leave the organization. According to Shaffer, Harrison, Gilley \& Luk (2001) lack of perceived organizational support in the minds of the employees is equal to lack of resources available to them, which may lead them to quit their jobs. Therefore, it is very important for organizations to improve their image in the minds of their employees, and they can do this by increasing their support to them (Feldman \& Thomas, 1992). Alarmingly, lack of perceived organizational support may result in employees becoming deceitful. Because employees who lack perceived organizational support tend to use impression management (IM) to obtain the much-needed support (Shore \& Wayne, 1993). According to Jones and Pittman, impression management is the act of deceiving one's fellow employees or superiors into thinking that one is a better employee than they actually are (1982).

What sets successful organizations apart from unsuccessful ones is the strength of their relationship with their employees. Organizations can enhance their relationship with their employees through improving their perceived organizational support. According to literature, perceived organizational support can be improved in a number of ways. For instance, favorable treatment has been shown to improve employees perceived organizational support (Saleem \& Amin, 2013; Wayne, Shore, \& Liden, 1997). Because it leads to mutual trust and respect, which are the hallmarks of a healthy employee-organization relationship (Chen, Aryee, \& Lee, 2005; Eisenberger, Armeli, Rexwinkel, Lynch, \& Rhoades, 2001; Cheung, 2000; Eisenberger et al., 1990). Reward is another method that organizations can use to generate and improve their perceived organizational support. Though it is crucial to note that reward will generate perceived organizational support only when the employees know that the rewards they are given are based on discretionary choices and not some other factors that are outside the control of the organization (Eisenberger, Cummings, Armeli, \& Lynch, 1997; Shore \& Wayne, 1993).

High levels of perceived organizational support is beneficial for both employees and the organization. According to Hochwarter, Witt, Treadway and Ferris (2006) high perceived organizational support would indicate to the employees that the organization is positioning them for success through providing necessary resources as well as rewarding them for their contributions. High levels of perceived organizational support reflect the idea that the organization cares for its employees' and appreciates their contributions and sacrifices for the organization. Additionally, high perceived organizational support strengthens the trust employees have in their organization, because it means the organization notices its employees hard work and is willing to meet its exchange obligations towards its employees (Blau, 2017; Aube et al., 2007; Organ \& Konovsky, 1989). Finally, perceived organizational support could see the organization through times of crisis, like the current COVID-19 pandemic, since it has been proven that perceived organizational support enhances the employees' commitment and performance (Aube et al., 2007).

The effect of perceived organizational support on employees' turnover intentions has been well documented (see for example, Kalidas \& Bahron, 2015; Tuzun \& Kalemci, 2011; DeConinck \& Johnson, 2009; Maertz Jr et al., 2007; Loi et al., 2006; Ferres et al., 2004; Stinglhamber \& Vandenberghe, 2003; Rhoades and Eisenberger, 2002; Shaffer et al., 2001; Wayne et al., 1997)

The link between high perceived organizational support and employees' affective commitment is well established in the literature. According to Gouldner's reciprocity concept (1960), employees' affective 
commitment to an organization can be enhanced by perceived organizational support in the following ways. Firstly, employees who enjoy high levels of perceived organizational support are overwhelmed by a sense of obligation to contribute to their organization's success and its prosperity, which leads them to become more affectively committed to the organization (Mowday, Porter, \& Steers, 2013; Serin, 2017; Wayne et al., 1997; Rousseau, 1989; Eisenberger et al., 1986; Schein, 1980). Secondly, perceived organizational support would fulfill the employees' socio-emotional needs for affiliation, approval, and esteem (Armeli, Eisenberger, Fasolo, \& Lynch, 1998; Eisenberger et al., 1986), which ultimately reinforces their affective commitment to the organization (Stinglhamber \& Vandenberghe, 2003). Finally, employees who receive adequate support from their organizations tend to report higher levels of comfort and competence, because they feel supported and valued by the organization, which enhances their affective commitment to the organization (Stinglhamber \& Vandenberghe, 2003; Eisenberger et al., 2001).

It is clear that perceived organizational support is positively correlated with affective commitment, and literature is filled with studies that have provided evidence for their correlation. For example, Kalidass and Bahron (2015) conducted a study in eight Malayan three-star hotels and concluded that high perceived organizational support enhanced employees' affective commitment. Earlier in 2009, Panaccio and Vandenberghe reached the same conclusion when they studied the relationship between perceived organizational support and affective commitment of the employees and managers of first author's network. Likewise, prison employees were shown to have improved affective commitment when sufficiently supported by their prisons (Aube et al., 2007; Serin, 2018). Maertz Jr and colleagues (2007) showed that social service providers' affective commitment was positively related to their perceived organizational support. Also, Loi et al. (2006) arrived at comparable results to the previously mentioned studies when studying practicing solicitors in Hong-Kong. Moreover, Makanjee et al. (2006) proved that radiographs affective commitment to their organizations is greatly affected by the organizational support they receive. Also, Ferres and colleagues (2004) concluded that public health organization employees' affective commitment is positively correlated with their perceived organizational support. In their study, Fuller, Barnett, Hester and Relyea (2003) reported that a chain convenient store's employees' affective commitment had a strong relationship with their perceived organizational support. In their study of a Belgian university graduates over a period of 9 years, Stinglhamber and Vandenberghe (2003) achieved similar results. Examining 70 studies in their literature review, Rhoades and Eisenberger concluded that perceived organizational support and affective commitment were positively correlated (2002). Conducting their study on 324 expatriates from 46 different countries, Shaffer et al. (2001) achieved comparable results. Additionally, Bihop et al. (2000) studied 380 production employees from a US manufacturing company and reported that affective commitment and perceived organizational support are strongly correlated. Also, Guzzo, Noonan and Elron (1994) studied expatriate managers from 63 companies and found that perceive organizational support significantly impacted their affective commitment. Finally, conducting their study in a large US company, Shore and Wayne (1993) reported that perceived organizational support was positively correlated to affective commitment. Though we have not found any studies conducted in a university environment, we feel confident that:

H3a: POS is positively correlated to the university staff's continuance commitment.

H3a: POS is positively correlated to the university staff's affective commitment. 
Literature is also clear about the fact that perceived organizational support improves employee performance. For instance, Byrne and Hochwarter (2008) reported their findings after studying a variety of jobs from a variety of industries and stated that employee performance is strongly and positively correlated to perceived organizational support. Similarly, Piercy, Cravens, Lane and Vorhies (2006) reported that the performance of salespeople was significantly affected by their perception of the organizational support. Also, Loi and colleagues (2006) found that perceived organizational support improved the performance of Hong-Kongese practicing solicitors. Additionally, studying customer service employees and sales representatives, Hochwarter et al. (2006) reported that perceived organizational support enhanced their performance greatly. Further, Shanock and Eisenberger (2006) studied 248 fulltime employees of a large electronics store and reported the same results. In their detailed literature review, which consisted of 70 studies, Rhodes and Eisenberger (2002) concluded that perceived organizational support has a positive relationship with employees' performance. Moreover, Tsui, Pearce, Porter and Tripoli (1997) reported the same results studying the employees of ten companies from five different industries. Lastly, studying a variety of jobs and organizations, Eisenberger and fellow researchers (1990) reported that affective commitment is positively related to their perceived organizational support. As a result, we hypothesize the following:

H3b: POS is positively correlated to the university staff's work effort.

\subsection{Organizational Commitment}

Organizational commitment is the psychological bond that employees develop with the organization they work at. Organizational commitment has been a hot topic in the organizational theory and organizational psychology literature, mainly because of its impact on employee performance (Benkhoff, 1997). Theoretically speaking, employees who report higher levels of commitment to their organizations are less likely to think about leaving the organization than those who report lower levels of commitment (Ferres et al., 2004). Therefore, we can think of employee commitment as the opposite of employee turnover. Scholars have identified varying types of and definitions for organizational commitment. Most notable is Meyer and Allen's paper in which the authors have identified three distinct types of organizational commitment, namely, affective commitment (AC), normative commitment (NC), and continuance commitment (CC) (1991). Of the three types of organizational commitment, affective commitment seems to be the most important. Because employees who are affectively committed remain in the organization because they want to, not because they think it is their moral duty to (normative commitment), nor because they feel they need to (continuance commitment) (Altun, 2017; Casper et al., 2011; Panaccio \& Vandenberghe, 2009; Aube et al., 2007; Rashid et al., 2003; Meyer et al., 1993). Nonetheless, Allen and Meyer defined affective commitment as "an affective or emotional attachment to the organization such that the strongly committed individual identifies with, is involved in, and enjoys membership in, the organization" (1990, p. 2).

In his review of the organizational commitment literature, Mercurio (2015) argues that affective commitment is the crux of organizational commitment, as opposed to normative and continuance commitment. Further emphasizing the importance of affective commitment, Aube et al. (2007) stated that, from a managerial point of view, affective commitment is more desirable when compared to normative and continuance commitment. This may be due to the fact that employees who are normatively committed 
to their organizations stay out of empathy for the organization, which in some sense may not be considered 'true' commitment. And employees who are continuance committed remain in the organization, because they need to. In other words, an employee may continue with an organization out of fear of losing what they have accomplished there, or they might stay because they have no other choice, which again cannot be considered 'genuine' commitment. According to Chen and Francesco (2003), employees develop affective commitment as a response to their positive work experience within an organization. Examples of positive experience could be career development opportunities, promotion, and good pay (Altun \& Tahir, 2020; Makanjee et al., 2006), which would result in the employees developing affective commitment as a symbol of their gratitude and appreciation for the organization (Aube et al., 2007). Since affective commitment is the 'real' psychological feeling that employees develop in response to the positive experience they have in their organizations, it makes sense to think that employees with high levels of affective commitment would not use impression management (IM) (Shore \& Wayne, 1993), though, remarkably, the authors could not find support for their sensible thinking.

As mentioned earlier, employee commitment is the opposite of employee turnover, so it comes as no surprise that many studies have examined the relationship of affective commitment to employee turnover and reported that their negative correlation. For instance, Newman et al. (2012) conducted a study across five multinational companies working in the Chinese service industry and found out that affective commitment was inversely related to employee turnover. Stinglhamber, and Vandenberghe (2003) researched the same conclusion, when they conducted a study on 1277 alumni from a Belgian university. Also, studying 324 expatriates who were working in 46 different countries, Shaffer and colleagues concluded that employees who reported high levels of affective commitment were less likely to quit their jobs (2001). Finally, studying a sample of 1413 employees from a large American corporation, Wayne et al. (1997) determined that employees' affective commitment and turnover intentions were inversely related.

The positive impact affective commitment has on employee performance is also clear, and there is ample evidence for it in the organizational theory and industrial psychology literature. For example, Casper and colleagues (2011) conducted their study on a sample of Brazilian professionals and confirmed the positive relationship between affective commitment and performance. Aube and fellow researchers (2007) achieved similar results when studying prison employees. Similar results were reported by Ferres et al. (2004) amongst public health organization employees. Likewise, Chen and Francesco (2003) conducted a study in a Chinese pharmaceutical manufacture and reported the positive effects of affective commitment on employee performance. Moreover, Bishop and colleagues (2000) arrived at the same results in the manufacturing sector. Additionally, when trying to examine the validity of the measures they came up with for the three types of organizational commitment, Allen and Meyer (1996) concluded that affective commitment enhances employee performance. Also, Angle and Lawson (1994) conducted a study in a Fortune500 multi-business manufacturing company and concluded that affective commitment was positively related to two of the four performance aspects analyzed, namely, initiative and dependability. Lastly, examining the data collected from nursing students for two academic years, Meyer and colleagues (1993) concluded that affective commitment and normative commitment were positively related to employee performance, while continuance commitment was inversely related. The above examples were from various sectors, jobs and organizations, which makes us confidently propose the following: 
H4a: $\mathrm{CC}$ is positively related to university staff's AC.

H4b: CC is positively related to university staff's work effort.

H5: AC is positively related to university staff's work effort.

\subsection{Lecturer Work Effort (Performance)}

In their paper, Maxham III, Netemeyer and Lichtenstein, differentiate between two types of employee performance, viz. employee in-role performance (EIRP) and employee extra-role performance (EERP) (2008). While employee in-role performance are the activities that an employee does and are part of the official job requirements (Borman \& Motowidlo, 1993), employee extra-role performance are everything else that the employee engages in voluntarily that benefits the organization in one way or another (Budur \& Poturak, 2021; Celik \& Yildiz, 2017; Maxham III, Netemeyer, \& Lichtenstein, 2008). The distinguishing characteristic between the two is that in-role performance are official requirements of the job, while extra-role performance is not. For the purpose of this paper, we take a more holistic approach to employee performance. In other words, we do not separate between in-role and extra-role performances, because we believe that intra-role and extra-role activities complement one another. To put it differently, employees engage in extra-role activities to enhance their intra-role performance. Hence, we define employee performance as everything that an employee does that benefits the organization, regardless of whether it is part of the formal job description or not.

High performing employees are important assets to in any organization irrespective of sector or business type. Because employees' performance can be the determining factor in the performance of the whole organization (Saleem \& Amin, 2013; Celik, 2020; DeConinck \& Johnson, 2009). This could not be truer for service organizations, universities in particular. Because university's quality and performance depend to a large extent on the employee-customer interaction (Demir et al., 2020). Therefore, the performance of the staff can determine the performance of the university and its success. According to research, anything that an employee is doing can be considered employee performance as long as it contributes to the organization's objectives and strategic aims (Anitha, 2014; Dessler, 2005; Viswesvaran \& Ones, 2000; Yildiz \& Budur, 2019). These contributions can be financial or non-financial (Anitha, 2014). Interestingly, research suggests that high performing employees like challenging working environments, because it encourages them to enhance their performance, otherwise they will get demotivated and think about leaving the organization (Elnaga \& Imran, 2013).

Given the importance of employee performance, we try, through this paper, to study the effects of perceived co-worker support (PCS), perceived supervisor support (PSS), and perceived organizational support (POS) on affective commitment (AC) on one hand, and on employee performance on the other. We also aim to shed light on the relationship between affective commitment (AC) and employees' performance. 


\subsection{Proposed Model of the Study}

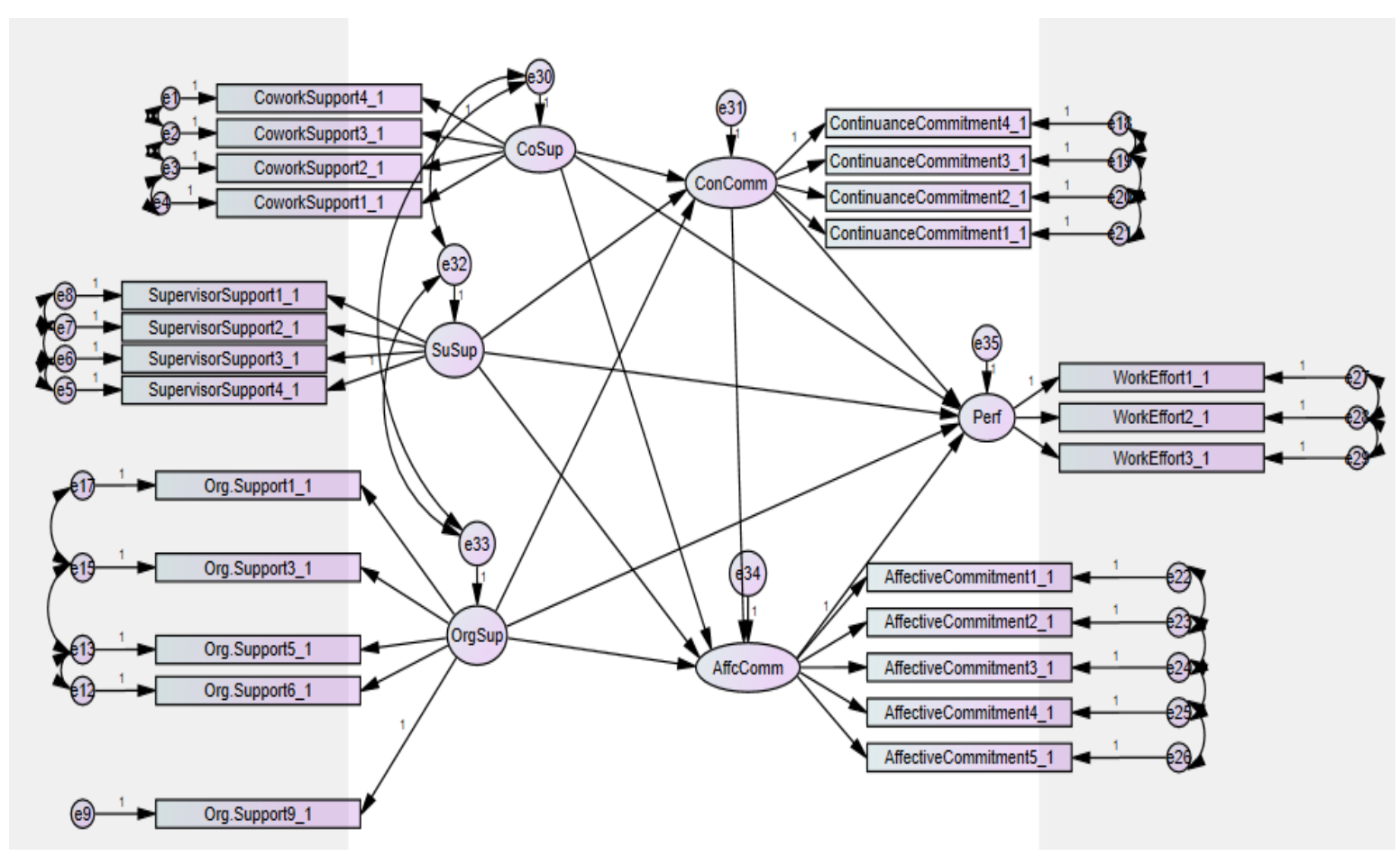

Figure 1: Model of the study

\section{Methodology}

\subsection{Purpose}

Purpose of the current study was to investigate the impact of co-worker support, supervisor support, and organizational support on the lecturers' commitment and work efforts at various universities. In this regard, we collected data from the private and public universities in the Kurdistan Region of Iraq. The data was collected using survey questionnaire. The collected data was analyzed using causal methodologies.

\subsection{Sample}

In line with the aim of the study, data was collected from university lecturers in the Kurdistan Region of Iraq. In total, 204 lecturers from various private and public universities joined the survey. Sixty two percent of the respondents were male, and $38 \%$ were female. Ten percent were from public universities, while $90 \%$ were from private universities. Besides, $64 \%$ of the lecturers were Kurdish, $15 \%$ were Arab, and $21 \%$ did not give information. Lastly, it has been observed that majority of the respondents have experience at university between five to ten years.

\subsection{Instrumentation}

The questionnaire of the study consisted of seven sections, which were demographics, perceived coworker support, perceived supervisor support, perceived organizational support, affective commitment, 
continuous commitment, and work effort. Items of the survey have been evaluated through 5-point Likert scale, where 1 represented "strongly disagree" and 5 represented "strongly agree". Further, the perceived support questions (17 questions) have been adopted from Burns, (2016), Imran et al., (2020), and Woo and Chelladurai, (2012). Commitment has nine questions and have been adopted from Dinc (2017), and Meyer et al., (1993). Lastly, work effort has three questions and measured the performance of the academic staff, which was adopted from Woo and Chelladurai (2012).

\subsection{Procedures}

The collected data was initially evaluated via validity and reliability tests. For validity, we used exploratory factor analysis (EFA) and confirmatory factor analysis (CFA). For EFA and Cronbach's Alpha, we utilized IBM SPSS software. For the reliability of the data, we used Cronbach's alpha, discriminant and convergent validities. After validation of the questionnaire, we conducted structural equations modeling (SEM). For CFA, discriminant validity, convergent validity, and SEM we utilized IBM AMOS software.

Additionally, we conducted Harman's common variance test for testing the common variance existence in the questionnaire. The results revealed that single factor was explaining only $24.93 \%$ of the overall variance. Hence, there is no common variance problem in the questionnaire due to the fact that single factor did not explain at least $50 \%$ of the variance.

The data was validated via EFA, CFA, and Reliability analysis. Lastly, we conducted discriminant validity and convergent validity to evaluate the internal appropriateness and distance of each dimension to each other. After the validity of the data, we conducted structural equations modeling (SEM) to test the hypothesized model.

\section{Research Findings}

\subsection{Validity and Reliability}

All potential measurement items of the study were rated 1 to 5 Likert's scale by the participants. As it can be seen on the Appendix I, there were initially 29 questions and six dimensions in the survey questionnaire. After the data collection, we tested the validity and reliability of the results. Initial results revealed that second, fourth, seventh, and eighth items of organizational support dimension held insufficient load in the communality values of EFA. Therefore, we subtracted the question from the further analyses. 
Table 1: Confirmatory factor analysis

\begin{tabular}{|c|c|c|c|c|c|c|c|c|}
\hline \multirow[t]{2}{*}{ Items } & \multirow[t]{2}{*}{ Mean } & \multirow[t]{2}{*}{ S.D. } & \multicolumn{6}{|c|}{ Component } \\
\hline & & & $\mathrm{AC}$ & OS & SS & $\mathrm{CS}$ & WE & $\mathrm{CC}$ \\
\hline CoworkSupport1 & 4.040 & 0.661 & 0.071 & 0.140 & 0.113 & 0.762 & 0.118 & -0.028 \\
\hline CoworkSupport2 & 4.157 & 0.726 & -0.019 & 0.096 & 0.128 & 0.766 & 0.253 & -0.042 \\
\hline CoworkSupport3 & 3.917 & 0.741 & 0.134 & 0.066 & 0.148 & 0.763 & 0.001 & -0.028 \\
\hline CoworkSupport4 & 4.044 & 0.796 & 0.017 & 0.159 & 0.184 & 0.758 & 0.104 & 0.016 \\
\hline SupervisorSupport1 & 3.995 & 0.868 & 0.014 & 0.188 & 0.731 & 0.132 & 0.242 & -0.018 \\
\hline SupervisorSupport2 & 3.961 & 0.887 & 0.002 & 0.321 & 0.749 & 0.163 & 0.052 & 0.061 \\
\hline SupervisorSupport3 & 3.765 & 0.917 & 0.072 & 0.161 & 0.722 & 0.204 & 0.225 & 0.095 \\
\hline SupervisorSupport4 & 3.770 & 0.983 & 0.030 & 0.266 & 0.783 & 0.195 & 0.076 & 0.032 \\
\hline Org.Support1 & 3.696 & 0.779 & 0.066 & 0.636 & 0.341 & 0.028 & 0.040 & 0.103 \\
\hline Org.Support3 & 3.583 & 0.853 & 0.134 & 0.710 & 0.259 & 0.100 & 0.019 & 0.098 \\
\hline Org.Support5 & 3.691 & 0.853 & 0.014 & 0.785 & 0.088 & 0.222 & 0.090 & 0.122 \\
\hline Org.Support6 & 3.647 & 0.783 & -0.067 & 0.776 & 0.077 & 0.065 & 0.027 & 0.036 \\
\hline Org.Support9 & 3.603 & 1.005 & 0.090 & 0.678 & 0.224 & 0.116 & 0.133 & 0.204 \\
\hline ContinuanceCommitment1 & 3.377 & 1.064 & -0.173 & 0.132 & 0.245 & -0.085 & -0.019 & 0.765 \\
\hline ContinuanceCommitment2 & 3.265 & 0.992 & 0.048 & 0.095 & 0.060 & -0.022 & 0.052 & 0.875 \\
\hline ContinuanceCommitment3 & 2.784 & 1.084 & 0.263 & 0.134 & -0.154 & -0.020 & -0.056 & 0.585 \\
\hline ContinuanceCommitment4 & 3.382 & 0.983 & 0.082 & 0.134 & -0.010 & 0.027 & 0.029 & 0.790 \\
\hline AffectiveCommitment1 & 2.828 & 1.094 & 0.768 & 0.042 & -0.135 & -0.012 & -0.042 & -0.019 \\
\hline AffectiveCommitment2 & 2.828 & 1.094 & 0.819 & 0.005 & -0.064 & 0.019 & -0.035 & -0.012 \\
\hline AffectiveCommitment3 & 2.873 & 1.138 & 0.816 & 0.086 & -0.065 & -0.016 & -0.027 & 0.015 \\
\hline AffectiveCommitment4 & 3.417 & 1.016 & 0.846 & 0.053 & 0.181 & 0.168 & 0.073 & 0.065 \\
\hline AffectiveCommitment5 & 3.412 & 1.035 & 0.849 & 0.036 & 0.208 & 0.104 & 0.111 & 0.133 \\
\hline WorkEffort1 & 4.201 & 0.765 & 0.018 & 0.071 & 0.162 & 0.194 & 0.874 & 0.070 \\
\hline WorkEffort2 & 4.039 & 0.708 & 0.071 & 0.121 & 0.160 & 0.096 & 0.856 & -0.039 \\
\hline WorkEffort3 & 4.275 & 0.777 & -0.019 & 0.050 & 0.148 & 0.145 & 0.863 & 0.006 \\
\hline $\begin{array}{l}\text { *** Extraction Method: Pr } \\
\text { *** Rotation Method: Var } \\
\text { *** Rotation converged in } \\
\text { *** AC: Affective commi } \\
\text { support; WE: Work effort }\end{array}$ & & & & & & & & \\
\hline
\end{tabular}

After subtracting the concerning items from the analysis, we tested the validity from the beginning. The results showed that Kaiser-Meyer-Olkin (KMO) test result was 0.81 , which is above the threshold 0.5 value. Secondly, Barlett's test of sphericity results revealed that approximated chi-square result was significant at $\mathrm{P}<0.01$. Hence, it was concluded that the data was sufficient to continue with the further analyses (Demir et al., 2021). 
Table 2: Convergent validity

\begin{tabular}{|c|c|c|c|c|c|c|}
\hline Dimensions & KMO & Eigen Value & $\begin{array}{c}\text { Extracted } \\
\text { variance }\end{array}$ & $\begin{array}{l}\text { Cronbach's } \\
\text { Alpha }\end{array}$ & AVE & C.R. \\
\hline Co-worker support & \multirow[t]{6}{*}{0.81} & 6.58 & 16.46 & 0.81 & 0.51 & 0.81 \\
\hline Supervisor support & & 4.05 & 11.39 & 0.85 & 0.61 & 0.86 \\
\hline $\begin{array}{l}\text { Organizational } \\
\text { support }\end{array}$ & & 2.28 & 9.94 & 0.82 & 0.51 & 0.84 \\
\hline $\begin{array}{l}\text { Continues } \\
\text { commitment }\end{array}$ & & 1.96 & 9.21 & 0.78 & 0.52 & 0.80 \\
\hline $\begin{array}{l}\text { Affective } \\
\text { commitment }\end{array}$ & & 1.74 & 8.71 & 0.94 & 0.64 & 0.81 \\
\hline Work effort & & 1.49 & 8.62 & 0.88 & 0.71 & 0.86 \\
\hline
\end{tabular}

Given in Table 2, we observed that there were six Eigen values which were above one so that the group of items could be considered as a dimension. Therefore, there are six dimensions as it has been planned for the questionnaire. Moreover, extracted variance of the questionnaire was $64 \%$ and the distribution of the variances were shown on the Table 2. It was observed that Cronbach's alpha values for each dimension was well above 0.7 to be considered as reliable latent variable. When Table 1 was evaluated, it was observed that items have been located the highest load under the designed variable. Check Table 1 for further details.

After the Exploratory factor analysis, we conducted confirmatory factor analysis. We used maximum likelihood estimator function for this operation. The results should be analyzed after observing the model fit values. For the model fit parameters, we observed comparative fit and absolute fit indexes. For the first index group, we observed comparative fit index (CFI), incremental fit index (IFI), and Trucker-Lewis fit index (TLI). However, for the absolute fit index group, we observed $\mathrm{x} 2 / \mathrm{df}$, root mean square error of approximation (RMSEA), goodness of fit index (GFI), and adjusted goodness of fit index (AGFI) values. Based on the results, CFI (0.97), IFI (0.97), and TLI (0.96) values all were above 0.9. Therefore, comparative fit values were appropriate. Furthermore, GFI (0.89) and AGFI (0.85) values were above minimum threshold while $\mathrm{x} 2 / \mathrm{df}$ (1.39) was less than 5, and RMSEA (0.044) was less than 0.1 value. Hence, absolute fit values were also sufficient to evaluate the standardized loads of each item. Lastly, the standardized loads of each item under the concerning latent variable was above 0.5. Thus, CFA results were considered to be survived.

Convergent and discriminant validity were tested as the final validity and reliability evaluation tests. Convergent validity requires average variance extracted (AVE) values minimally 0.5 and composite reliability (C.R.) values minimally 0.7. Given in Table 2, least value of AVE was 0.5 and the C.R. was 0.8 , hence, convergent validity was achieved. Secondly, discriminant validity requires that square root of average variance extracted for each latent variable must hold higher value comparing to the correlation value of that variable with other dimensions. Based on the results in Table 3, this objective was achieved. Thus, discriminant validity was also achieved. 
Table 3: Discriminant validity

\begin{tabular}{|l|r|r|r|r|r|r|}
\hline Dimension & 1 & 2 & 3 & 4 & 5 & 6 \\
\hline Co-worker Support & 0.720 & & & & & \\
\hline Supervisor support & 0.516 & 0.773 & & & & \\
\hline Organizational support & 0.430 & 0.661 & 0.711 & & & \\
\hline Continuous commitment & -0.001 & 0.201 & 0.405 & 0.711 & & \\
\hline Affective commitment & 0.066 & 0.011 & 0.118 & 0.083 & 0.799 & \\
\hline Work effort & 0.438 & 0.429 & 0.292 & 0.107 & -0.039 & 0.840 \\
\hline
\end{tabular}

*** Bold numbers represent square root of AVE while normal numbers are the correlation values.

\subsection{Hypotheses Testing}

After the validity and reliability tests, we conducted structural equations modeling (SEM) to test the hypothesized model of the study. The results reveled that coworker support significantly affected the continuous commitment of lecturers. Besides, this impact was negative. Hence, when the lecturers come together and support each other, this leverages their continues commitment negatively. Further, we found that organizational support influence continuous commitment of employee significantly and positively. It shows that when the organization supports employees and motivates them, it affects the continuous commitment of employees. Lastly, we couldn't find any relation between supervisor support and continuous commitment of employees. This result shows that supervisor support does not sense anything to increase the continuous commitment of employees. In this regard, H1a and H3a have been accepted whilst $\mathrm{H} 2 \mathrm{a}$ was rejected.

Secondly, we investigated the antecedents of affective commitment. It was revealed from the analyses that neither co-worker support, nor supervisor support, organizational support, and continues commitment affected the affective commitment of employees. The results revealed that those parameters are not the determinants of affective commitment. Hence, H1b, H2b, H3b, and H4a were rejected.

Lastly, we evaluated the effects of the independent variables on the work efforts of employees. The results showed that co-worker support and supervisor support were both affecting the work effort of lecturers. It shows that when the supervisor motivates and supports lecturers, and the staff support and motivate each other, it boosts their efforts positively. Besides, we could not find any significant effects of organizational support, continuous commitment, and affective commitment on the work effort of employees. Thus, H1c and $\mathrm{H} 2 \mathrm{c}$ were accepted whilst $\mathrm{H} 5, \mathrm{H} 4 \mathrm{~b}$, and $\mathrm{H} 3 \mathrm{c}$ were rejected. 
Table 4: Hypotheses results

\begin{tabular}{|c|c|c|c|c|c|c|}
\hline H no & $\begin{array}{c}\text { Dependent } \\
\text { Variables }\end{array}$ & & $\begin{array}{c}\text { Independent } \\
\text { Variables }\end{array}$ & Direct & Indirect & Result \\
\hline H1a & $\begin{array}{l}\text { Continuous } \\
\text { Commitment }\end{array}$ & $<--$ & $\begin{array}{l}\text { Co-worker } \\
\text { Support }\end{array}$ & $-0.273^{*}$ & - & Supported \\
\hline $\mathrm{H} 2 \mathrm{a}$ & $\begin{array}{l}\text { Continuous } \\
\text { Commitment }\end{array}$ & $<--$ & $\begin{array}{l}\text { Supervisor } \\
\text { Support }\end{array}$ & $-0.031^{\mathrm{P}>0.05}$ & - & $\begin{array}{l}\text { Not } \\
\text { Supported }\end{array}$ \\
\hline $\mathrm{H} 3 \mathrm{a}$ & $\begin{array}{l}\text { Continuous } \\
\text { Commitment }\end{array}$ & $<--$ & $\begin{array}{l}\text { Organizational } \\
\text { Support }\end{array}$ & $0.506^{\mathrm{P}>0.05}$ & - & Supported \\
\hline $\mathrm{H} 1 \mathrm{~b}$ & $\begin{array}{l}\text { Affective } \\
\text { Commitment }\end{array}$ & $<--$ & $\begin{array}{l}\text { Co-worker } \\
\text { Support }\end{array}$ & $0.111^{\mathrm{P}>0.05}$ & $-0.01^{\mathrm{P}>0.05}$ & $\begin{array}{l}\text { Not } \\
\text { Supported }\end{array}$ \\
\hline $\mathrm{H} 2 \mathrm{~b}$ & $\begin{array}{l}\text { Affective } \\
\text { Commitment }\end{array}$ & <--- & $\begin{array}{l}\text { Supervisor } \\
\text { Support }\end{array}$ & $-0.161^{\mathrm{P}>0.05}$ & $0.01^{\mathrm{P}>0.05}$ & $\begin{array}{l}\text { Not } \\
\text { Supported }\end{array}$ \\
\hline $\mathrm{H} 3 \mathrm{~b}$ & $\begin{array}{l}\text { Affective } \\
\text { Commitment }\end{array}$ & $<--$ & $\begin{array}{l}\text { Organizational } \\
\text { Support }\end{array}$ & $0.196^{\mathrm{P}>0.05}$ & $0.03^{\mathrm{P}>0.05}$ & $\begin{array}{l}\text { Not } \\
\text { Supported }\end{array}$ \\
\hline $\mathrm{H} 4 \mathrm{a}$ & $\begin{array}{l}\text { Affective } \\
\text { Commitment }\end{array}$ & $<--$ & $\begin{array}{l}\text { Continuous } \\
\text { Commitment }\end{array}$ & $0.055^{\mathrm{P}>0.05}$ & - & $\begin{array}{l}\text { Not } \\
\text { Supported }\end{array}$ \\
\hline $\mathrm{H} 5$ & Work Effort & $<--$ & $\begin{array}{l}\text { Affective } \\
\text { Commitment }\end{array}$ & $-0.049^{\mathrm{P}>0.05}$ & - & $\begin{array}{l}\text { Not } \\
\text { Supported }\end{array}$ \\
\hline $\mathrm{H} 4 \mathrm{~b}$ & Work Effort & <--- & $\begin{array}{l}\text { Continuous } \\
\text { Commitment }\end{array}$ & $0.075^{\mathrm{P}>0.05}$ & $0.05^{\mathrm{P}>0.05}$ & $\begin{array}{l}\text { Not } \\
\text { Supported }\end{array}$ \\
\hline $\mathrm{H} 1 \mathrm{c}$ & Work Effort & $<--$ & $\begin{array}{l}\text { Co-worker } \\
\text { Support }\end{array}$ & $0.401 * * *$ & $-0.02^{\mathrm{P}>0.05}$ & Supported \\
\hline $\mathrm{H} 2 \mathrm{c}$ & Work Effort & $<--$ & $\begin{array}{l}\text { Supervisor } \\
\text { Support }\end{array}$ & $0.254 * * *$ & $0.01^{\mathrm{P}>0.05}$ & Supported \\
\hline $\mathrm{H} 3 \mathrm{c}$ & Work Effort & $<--$ & $\begin{array}{l}\text { Organizational } \\
\text { Support }\end{array}$ & $-0.057^{P>0.05}$ & $0.02^{\mathrm{P}>0.05}$ & $\begin{array}{l}\text { Not } \\
\text { Supported }\end{array}$ \\
\hline
\end{tabular}

\section{Discussion}

The results revealed that co-worker support was affecting continuous commitment negatively. There might be several reasons for this surprising result. Firstly, the employees might be talking negatively about the company when they come together. As result, this might be affecting their commitment negatively. Secondly, the company might not be satisfying the demands of its employees by means of finance and motivation, and in return, employees might be coming together and discussing those dissatisfactions which might be negatively affecting the employees' commitment.

Another finding of the study reveals that supervisors' support does not significantly affect the employees' commitment. Besides, organizational support significantly affects commitment of employees directly. The result reveals that support of supervisor is not a determinant for the commitment to the company, but the organizational support is. The reason behind this might be that the lecturers might not be considering the supervisor as the one of the top components of the organization and therefore, the support of the supervisor might not be perceived as the support from the organization.

The results have shown that coworker support affects the work effort positively. This result shows that when the employees are coming together and supporting themselves, this positively influences their work 
effort despite the fact that they are not committed to the organization. This might be because of losing their jobs and keeping their career on. It might be revealed that the employees are working with higher effort not because they are committed to the organization, but they do not want to lose their jobs or improve their self-career.

It was observed that supervisors support also was influencing employees' work effort positively. Based on this result, it can be revealed that employees are motivated to do it better when they face a positive attitude from their supervisors. These results are similar to Saleem and Amin (2013). Interestingly, it was observed that the impact of co-worker supports on employees are greater than the impact of supervisor's support. This might be due to the informality aspect of the co-worker relationships, which means they can ask their colleagues for help and guidance without the fear of being judged or seen as incompetent.

Lastly, it was observed that commitment did not impact the employees' work effort. The reason behind this might be that when employees are not committed enough, they do not feel the need to work harder and more conveniently. It might also be showing that the employees' lack of commitment to the organization but still working not to lose their jobs.

\section{Summary and Practical Implications}

The purpose of the current study was to elaborate the impact of support on the university faculty members' commitments and work efforts. The results showed that organizational support was the only support which increased the university lecturers' commitment. Therefore, the top management of the organization should consider supporting employees' good attitudes and work behaviors through recognizing their efforts by rewarding them. Secondly, the organizations should consider effective training programs which show that the organization makes long term investment in its employees and in return, the employees would be more committed to the organization.

Given in the results, supervisor support was one of the vital and significant determinants of lecturers' work efforts. Given in these results, supervisors are suggested to motivate their subordinates and recognize their positive work behaviors. In return, their work efforts are expected to increase.

Based on the results, it was observed that commitment was ineffective determinant on the lecturers' work efforts. In this regard, we suggest more researches in this field to test the impact of support on staff' commitment, and in return impact of commitment on their work efforts. However, the future researchers might be considering the fear to lose the job as a mediator effect between support and work effort. Hence, one of the important limitations of the study could be the Covid-19 that has changed the lecturer's perception since the data have been collected during the pandemic process. In addition, future studies can add some questions about the covid perceptions respectively.

\section{References}

Allen, N. J., \& Meyer, J. P. (1996). Affective, continuance, and normative commitment to the organization: An examination of construct validity. Journal of Vocational Behavior, 49(3), 252-276.

Altun, M. (2017). The effects of teacher commitment on student achievement. International Journal of Social Sciences \& Educational Studies, 3(3), 51. 
Altun, M., \& Tahir, R. (2020). Motivational Techniques in EFL Classrooms in the Universities of Kurdistan. International Journal of Social Sciences \& Educational Studies, 7(1), 88-94.

Angle, H. L., \& Lawson, M. B. (1994). Organizational commitment and employees' performance ratings: Both type of commitment and type of performance count. Psychological Reports, 75(3_suppl), 1539-1551.

Aube, C., Rousseau, V., \& Morin, E. M. (2007). Perceived organizational support and organizational commitment. Journal of Managerial Psychology, 22(5), 479-495.

Bishop, J. W., Scott, K. D., \& Casino, L. S. (1997). The differential effects of team commitment and organizational commitment on job performance and intention to quit. Paper presented at the Annual Meeting of the Academy of Management, Boston.

Borman, W. C., \& Motowidlo, S. M. (1993). Expanding the criterion domain to include elements of contextual performance.

Budur, T. (2018). The impact of Al-Ghazali's virtues on organizational commitment and performance: A case Study at private education institutions in Kurdistan Region of Iraq. Icabep, Erbil-Iraq, 2, p21.

Budur, T., \& Demir, A. (2019). Leadership perceptions based on gender, experience, and education. International Journal of Social Sciences \& Educational Studies, 6(1), 142-154.

Budur, T., \& Poturak, M. (2021). Transformational leadership and its impact on customer satisfaction. Measuring mediating effects of organisational citizenship behaviours. Middle East Journal of Management, 8(1), 67-91.

Budur, T., Demir, A., \& Cura, F. (2021). University Readiness to Online Education during Covid-19 Pandemic. International Journal of Social Sciences and Educational Studies, 8(1), 180-200.

Caplan, R. D., Cobb, S., French, J. R. P., Jr., Harrison, R. V., \& Pinneau, S. R., Jr. (1975). Job demands and worker health: Main effects and occupational differences (U.S. Department of Health, Education, and Welfare HEW Publication No. 75-160). Ann Arbor: Institute for Social Research, University of Michigan.

Casper, W. J., Harris, C., Taylor-Bianco, A., \& Wayne, J. H. (2011). Work-family conflict, perceived supervisor support and organizational commitment among Brazilian professionals. Journal of Vocational Behavior, 79(3), 640-652.

Celik, B. (2020). An investigation of the attitudes of teachers on the use of newspapers in the teaching of Turkish as a foreign language according to some variables. International Journal of Social Sciences \& Educational Studies, 7(3), 130-147.

Celik, B., \& Yildiz, Y. (2017). Commitment to the teaching profession. International Journal of Social Sciences \& Educational Studies, 4(2), 93-97.

Chiaburu, D. S., \& Harrison, D. A. (2008). Do peers make the place? Conceptual synthesis and metaanalysis of co-worker effects on perception, attitudes, OCBs, and performance. Journal of Applied Psychology, 93, 1082-1103.

DeConinck, J. B., \& Johnson, J. T. (2009). The effects of perceived supervisor support perceived organizational support, and organizational justice on turnover among salespeople. Journal of Personal Selling \& Sales Management, 29(4), 333-350.

Demir, A. (2020). Impact of Internal Marketing on the Customer Perceptions in SMEs. International Journal of Services and Operations Management. DOI: 10.1504/IJSOM.2020.10033103

Demir, A., \& Budur, T. (2019). Roles of leadership styles in corporate social responsibility to nongovernmental organizations (NGOs). International Journal of Social Sciences \& Educational Studies, 5(4), 174-183.

Demir, A., Budur, T., \& Heshmati, A. (2020). Antecedents of trust, corporate image, and switching costs: A case in telecommunication services in Kurdistan Region of Iraq. International Journal of Mobile Communications. DOI: 10.1504/IJMC.2021.10030758 
Demir, A., Budur, T., Hiwa, M., \& Heshmati, A. (2021). Links between Knowledge Management and Organizational Sustainability: Does the ISO 9001 certification have an effect? Knowledge Management Research \& Practice (TKMR), Doi: 10.1080/14778238.2020.1860663

Demir, A., Maroof, L., Khan, N. U. S., \& Ali, B. J. (2020). The role of E-service quality in shaping online meeting platforms: a case study from higher education sector. Journal of Applied Research in Higher Education. DOI: 10.1108/JARHE-08-2020-0253

Dinc, M. S. (2017). Organizational commitment components and job performance: Mediating role of job satisfaction. Pakistan Journal of Commerce and Social Sciences (PJCSS), 11(3), 773-789.

Dirks, K. T., \& Ferrin, D. L. (2002). Trust in leadership: Meta-analytic findings and implications for research and practice. Journal of Applied Psychology, 87(4), 611-628.

Durmaz, O. (2017). Investigation of the motivation parameters in health care establishments. International Journal of Social Sciences \& Educational Studies, 3(4), 44-53.

Eisenberger, R., Fasolo, P., \& Davis-LaMastro, V. (1990). Perceived organizational support and employee diligence, commitment, and innovation. Journal of Applied Psychology, 75(1), 5159.

Eisenberger, R., Stinglhamber, F., Vandenberghe, C., Sucharski, I. L., \& Rhoades, L. (2002). Perceived supervisor support: contributions to perceived organizational support and employee retention. Journal of Applied Psychology, 87(3), 565.

Elnaga, A., \& Imran, A. (2013). The effect of training on employee performance. European journal of Business and Management, 5(4), 137-147.

Feldman, D. C., \& Thomas, D. C. (1992). Career management issues facing expatriates. Journal of International Business Studies, 23(2), 271-293.

Ferres, N., Connell, J., \& Travaglione, A. (2004). Co-worker trust as a social catalyst for constructive employee attitudes. Journal of Managerial Psychology, 19(6), 608-622.

Fuller, J. B., Barnett, T., Hester, K., \& Relyea, C. (2003). A social identity perspective on the relationship between perceived organizational support and organizational commitment. The Journal of Social Psychology, 143(6), 789-791.

Gentry, W. A., Kuhnert, K. W., Mondore, S. P., \& Page, E. E. (2006). The influence of supervisorysupport climate and unemployment rate on part-time employee retention. Journal of Management Development, 26(10), 1005-1022.

Guzzo, R. A., Noonan, K. A., \& Elron, E. (1994). Expatriate managers and the psychological contract. Journal of Applied Psychology, 79, 617-626.

Hochschild, A. R. (2012). The managed heart: Commercialization of human feeling. Univ of California Press.

Hochwarter, W. A., Witt, L. A., Treadway, D. C., \& Ferris, G. R. (2006). The interaction of social skill and organizational support on job performance. Journal of Applied Psychology, 91(2), 482489.

Hutchison, S. (1997). A path model of perceived organizational support. Journal of Social Behavior and Personality, 12(1), 159-174.

Imran, M. Y., Elahi, N. S., Abid, G., Ashfaq, F., \& Ilyas, S. (2020). Impact of perceived organizational support on work engagement: Mediating mechanism of thriving and flourishing. Journal of Open Innovation: Technology, Market, and Complexity, 6(3), 82.

Kalidass, A., \& Bahron, A. (2015). The relationship between perceived supervisor support, perceived organizational support, organizational commitment and employee turnover intention. International Journal of Business Administration, 6(5), 82-89.

Kavlu, A. (2020). Professional Development Needs of Private and Public High Schools EFL Teachers in Erbil-Kurdistan. International Journal of Social Sciences \& Educational Studies, 7(3), 191.

Korczynski, M. (2003). Communities of coping: collective emotional labour in service work. Organisation, 10, 55-79. 
Kottke, J. L., \& Sharafinski, C. E. (1988). Measuring perceived supervisory and organizational support. Educational and Psychological Measurement, 48, 1075-1079.

Limpanitgul, T., Robson, M. J., Gould-Williams, J., \& Lertthaitrakul, W. (2013). Effects of co-worker support and customer cooperation on service employee attitudes and behaviour: Empirical evidence from the airline industry. Journal of Hospitality and Tourism Management, 20, 23 33.

Loi, R., Hang-Yue, N., \& Foley, S. (2006). Linking employees' justice perceptions to organizational commitment and intention to leave: The mediating role of perceived organizational support. Journal of Occupational and Organizational Psychology, 79(1), 101-120.

Lynch, P. D., Eisenberger, R., \& Armeli, S. (1999). Perceived organizational support: Inferior versus superior performance by wary employees. Journal of Applied Psychology, 84(4), 467-483.

Maertz Jr, C. P., Griffeth, R. W., Campbell, N. S., \& Allen, D. G. (2007). The effects of perceived organizational support and perceived supervisor support on employee turnover. Journal of Organizational Behavior: The International Journal of Industrial, Occupational and Organizational Psychology and Behavior, 28(8), 1059-1075.

Makanjee, C. R., Hartzer, Y. F., \& Uys, I. L. (2006). The effect of perceived organizational support on organizational commitment of diagnostic imaging radiographers. Radiography, 12(2), 118126.

Mart, Ç. T. (2013). Commitment to school and students. International Journal of Academic Research in Business and Social Sciences, 3(1), 336-340.

Mart, Ç. T. (2013). A passionate teacher: Teacher commitment and dedication to student learning. International Journal of Academic Research in Progressive Education and Development, 2(1), 437-442.

Mercurio, Z. A. (2015). Affective commitment as a core essence of organizational commitment: An integrative literature review. Human Resource Development Review, 14(4), 389-414.

Meyer, J. P., \& Allen, N. J. (1991). A three-component conceptualization of organizational commitment. Human Resource Management Review, 1(1), 61-89.

Meyer, J. P., Allen, N. J., \& Smith, C. A. (1993). Commitment to organizations and occupations: Extension and test of a three-component conceptualization. Journal of Applied Psychology, 78(4), 538-551.

Mohammed, S. S., \& Shahin, O. (2020). Service quality perspectives in telecommunication sector: Trust and loyalty investigation. Amazonia Investiga, 9(28), 394-403.

Mohammed, S. S., Suleyman, C., \& Taylan, B. (2020). Burnout Determinants and Consequences Among University Lecturers. Amazonia Investiga, 9(27), 13-24.

Mowday, R. T., Porter, L. W., \& Steers, R. M. (2013). Employee-organization linkages: The psychology of commitment, absenteeism, and turnover. Academic press.

Newman, A., Thanacoody, R., \& Hui, W. (2012). The effects of perceived organizational support, perceived supervisor support and intra-organizational network resources on turnover intentions: A study of Chinese employees in multinational enterprises. Personnel Review, 41(1), 56-72.

Organ, D. W., \& Konovsky, M. (1989). Cognitive versus affective determinants of organizational citizenship behavior. Journal of Applied Psychology, 74(1), 157-164.

Panaccio, A., \& Vandenberghe, C. (2009). Perceived organizational support, organizational commitment and psychological well-being: A longitudinal study. Journal of Vocational Behavior, 75(2), 224-236.

Payne, S. C., \& Huffman, A. H. (2005). A longitudinal examination of the influence of mentoring on organizational commitment and turnover. Academy of Management Journal, 48(1), 158-168. 
Poturak, M., Mekić, E., Hadžiahmetović, N., \& Budur, T. (2020). Effectiveness of Transformational Leadership among Different Cultures. International Journal of Social Sciences \& Educational Studies, 7(3), 119-129.

Rashid, C. A., Salih, H. A., \& Budur, T. (2020). The role of online teaching tools on the perception of the students during the lockdown of Covid-19. International Journal of Social Sciences \& Educational Studies, 7(3), 178.

Rashid, Z. A., Sambasivan, M., \& Johari, J. (2003). The influence of corporate culture and organisational commitment on performance. Journal of Management Development, 22(8), 708-728.

Rayton, B. A. (2006). Examining the interconnection of job satisfaction and organisationl commitment: an application of the bivariate probit model. International Journal of Human Resource Management, 17, 139154.

Rhoades, L., Eisenberger, R., \& Armeli, S. (2001). Affective commitment to the organization: The contribution of perceived organizational support. Journal of applied psychology, 86(5), 825836.

Rousseau, D. M. (1989). Psychological and implied contracts in organizations. Employee Responsibilities and Rights Journal, 2(2), 121-139.

Saleem, S., \& Amin, S. (2013). The impact of organizational support for career development and supervisory support on employee performance: An empirical study from Pakistani academic sector. European Journal of Business and Management, 5(5), 194-207.

Schein, E. (1980). Organizational Psychology, 3rd edn. Englewood Cliffs, Nj: Prentice Hall.

Serin, H. (2017). The role of Passion in Learning and Teaching. International Journal of Social Sciences \& Educational Studies, 4(1), 60-64.

Serin, H. (2018). The use of extrinsic and intrinsic motivations to enhance student achievement in educational settings. International Journal of Social Sciences \& Educational Studies, 5(1), 191-194.

Shanock, L. R., \& Eisenberger, R. (2006). When supervisors feel supported: Relationships with subordinates' perceived supervisor support, perceived organizational support, and performance. Journal of Applied psychology, 91(3), 689-695.

Shore, L. M., \& Shore, T. H. (1995). Perceived organizational support and organizational justice. Organizational politics, justice, and support: Managing the social climate of the workplace, 149, 164.

SULICH, A. (2019). The Green Management. Vision, 2025, 10043-10049.

Thoits, P. A. (1983). Dimensions of life events that influence psychological distress: An evaluation and synthesis of the literature. In Psychosocial Stress (pp. 33-103). Academic Press.

Torlak, N. G., Kuzey, C., Dinc, MS., \& Budur, T. (2021). Links connecting nurses' planned behavior, burnout, job satisfaction and organizational citizenship behavior. Journal of Workplace Behavioral Health. Doi:10.1080/15555240.2020.1862675

Torlak, N.G., Demir, A. and Budur, T. (2021), "Decision-making, leadership and performance links in private education institutes", Rajagiri Management Journal, Vol. ahead-of-print No. ahead-ofprint. https://doi.org/10.1108/RAMJ-10-2020-0061

Tsui, A. S., Pearce, J. L., Porter, L. W., \& Tripoli, A. M. (1997). Alternative approaches to the employee organization relationship: does investment in employees pay off? Academy of Management Journal, 40, 1089-1121.

Tuzun, I. K., \& Kalemci, R. A. (2011). Organizational and supervisory support in relation to employee turnover intentions. Journal of Managerial Psychology, 27(5), 518-534.

Viswesvaran, C., \& Ones, D. S. (2000). Perspectives on models of job performance. International Journal of Selection and Assessment, 8(4), 216-226. 
Wayne, S. J., Shore, L. M., \& Liden, R. C. (1997). Perceived organizational support and leader-member exchange: a social exchange perspective. Academy of Management Journal, 40, 82-111.

Woo, B., \& Chelladurai, P. (2012). Dynamics of perceived support and work attitudes: The case of fitness club employees. Human Resource Management Research, 2(1), 6-18.

Yildiz, Y., \& Budur, T. (2019). Introducing environmental awareness to college students with curricular and extracurricular activities. International Journal of Academic Research in Business and Social Sciences, 9(3), 667-675.

Zaim, H., Demir, A., \& Budur, T. (2020). Ethical leadership, effectiveness and team performance: An Islamic perspective. Middle East Journal of Management, 8(1), 42-66.

Zema, T., \& Sulich, A. (2019). Relations in the interorganizational networks. International Journal of Social Sciences \& Educational Studies, 6(1), 111-121. 